\title{
Peranan Bokashi Batang Pisang Dalam Meningkatkan Pertumbuhan Dan Hasil Bawang Daun (Alium fistulosum L.) Pada Tanah PMK
}

\author{
Nining Sri Sukasih dan Endy Prisstiawan \\ Fakultas Pertanian Universitas Kapuas Sintang \\ Email: niningskasih@g.mail.com
}

\begin{abstract}
Abstrak: Bawang daun merupakan salah satu jenis tanaman pertanian yang penting karena banyak mengandung gizi, dan diperlukan oleh manusia. Hasil panen bawang daun di Kalimantan Barat masih rendah, oleh karenanya perlu ditingkatkan. Salah satu kendala dalam meningkatkan pertumbuhan dan hasil bawang daun di Kalimantan Barat adalah tanahnya yang didominasi oleh tanah PMK. Tanah PMK merupakan jenis tanah yang miskin bahan organik, oleh karenanya perlu penambahan pupuk organik, antara lain dengan pemberian bokashi batang pisang. Penelitian ini bertujuan untuk mengetahui peranan bokashi batang pisang dalam meningkatkan pertumbuhan dan hasil bawang daun pada tanah PMK. Penelitian ini menggunakan metode Rancangan Acak Kelompok (RAK), yang terdiri atas 5 perlakuan yaitu : $\mathrm{b}_{0}=$ tanpa bokashi batang pisang, $\mathrm{b}_{1}$ $=$ bokashi batang pisang $0,50 \mathrm{~kg}$ per $\mathrm{m}^{2}, \mathrm{~b}_{2}=$ bokashi batang pisang $1,00 \mathrm{~kg}$ per $\mathrm{m}^{2}, \mathrm{~b}_{3}=$ bokashi batang pisang $1,50 \mathrm{~kg}$ per $\mathrm{m}^{2}, \mathrm{~b}_{4}=$ bokashi batang pisang 2,00 $\mathrm{kg}$ per $\mathrm{m}^{2}$.Parameter yang diamati adalah tinggi tanaman $(\mathrm{cm})$, jumlah daun per rumpun (helai), berat segar tanaman per rumpun $(\mathrm{kg})$.Data dianalisis dengan uji beda nyata jujur (BNJ) pada taraf 0,05 dan 0,01 . Hasil penelitian menunjukkan bahwa bokashi batang pisang berpengaruh terhadap pertumbuhan dan bawang daun, yang ditunjukkan oleh peubah tinggi tanaman, jumlah daun, dan berat tanaman. Pertumbuhan dan hasil tertingi akibat pemberian bokashi batang pisang dicapai pada dosis $1,50 \mathrm{~kg}$ per $\mathrm{m}^{2}$, pada dosis tersebut menghasilkan rerata tinggi tanaman $40,700 \mathrm{~cm}$, rerata jumlah daun per rumpun 32,500 helai, dan rerata berat tanaman per rumpun $0,261 \mathrm{~kg}$.
\end{abstract}

Kata Kunci : Pertumbuhan, Hasil, Bawang Daun, Bokashi Batang Pisang, Tanah Podsolik Merah kuning (PMK)

\section{PENDAHULUAN}

Bawang daun (Alium

fistulosum L.) merupakan salah satu

komoditas pertanian yang cukup

penting. Bawang daun sudah cukup

dikenal oleh masyarakat Indonesia

umumnya dan kabupaten Sintang

khususnya. Selain sudah cukup

dikenal, bawang daun merupakan

salah satu jenis tanaman yang mempunyai banyak manfaat. Sunaryono (2013:4) menjelaskan bahwa manfaat bawang daun antara lain adalah sebagai bahan pembuat obat seperti obat luka bakar. Lebih lanjut dijelaskan bahwa manfaat lain dari bawang daun adalah sebagai penyedap masakan karena rasanya enak. Wibowo (2014:13) menjelaskan bahwa selain rasanya 
Peranan Bokashi Batang Pisang Dalam Meningkatkan Pertumbuhan Dan Hasil Bawang Daun (Alium fistulosum L.) Pada Tanah PMK

yang enak, bawang daun juga banyak mengandung gizi. Kandungan gizi dari bawang daun adalah: protein $(1,5 \%)$, karbohidrat $(9,2 \%)$, lemak $(0,03 \%)$, beta karoten (50 IU), riboflavin $(0,04 \mathrm{mg}$ per $100 \mathrm{~g})$, thiamin (30 $\mathrm{mg}$ per $100 \mathrm{~g}$ ), niasin (20 mg per $100 \mathrm{~g}$ ), dan kalium sebanyak 334 mg per 100 g (Sugeng, 2013:1-2).

Berkaitan dengan kegunaan dan kandungan gizi pada bawang daun, hasil tanaman ini per satuan luas di kabupaten Sintang perlu ditingkatkan, mengingat hasilnya masih rendah. Rerata hasil bawang daun di kabupaten Sintang adalah 0,55 ton per ha, hasil tersebut lebih rendah dibandingkan dengan rerat hasil di Kalimantan Barat, dan potensi hasilnya. Rerata hasil panen bawang daun di Kalimantan Barat adalah 3,54 ton per ha (Badan Pusat Statistik Kalimantan Barat, 2018:200). Menurut Wobowo (2014:64), potensi hasil bawang daun yaitu 18,00 ton per ha. Upaya peningkatan hasil bawang daun di kabupaten Sintang menemui kendala, mengingat tanah yang banyak tersedia adalah tanah Podsolik Merah Kuning (PMK). BPS Kabupaten
Sintang (2018:5) menjelaskan bahwa luas tanah PMK di kabupaten Sintang adalah 0,93 juta ha $(42,89 \%$ dari luas wilayah kabupaten Sintang). Tanah PMK untuk mengusahakan tanaman bawang daun selain mempunyai potensi, juga mempunyai keterbatasan. Hakim, dkk. (1996:340) menjelaskan bahwa keterbatasan pada tanah PMK antara lain miskin bahan organik.

Tanah PMK yang miskin bahan organik tersebut perlu dicari solusinya, antara lain dengan pemberian pupuk organik. Salah satu pupuk organik yang banyak tersedia di kabupaten Sintang adalah pupuk organik yang berbahan dasar batang pisang, diantaranya yaitu bokashi batang pisang. Mengatasi kekurangan tanah PMK untuk tanaman bawang daun dengan pemberian bokashi batang pisang merupakan langkah yang dapat dipertanggung jawabkan, mengingat batang pisang di kabupaten Sintang selama ini belum dimanfaatkan. Pemanfaatan batang pisang untuk dijadikan pupuk dapat menyumbang bahan organik ke dalam tanah, yang pada akhirnya akan memacu aktifitas mikro-orgnisme tanah, dan 
Peranan Bokashi Batang Pisang Dalam Meningkatkan Pertumbuhan Dan Hasil Bawang Daun (Alium fistulosum L.) Pada Tanah PMK

selanjutnya meningkatkan

ketersediaan hara bagi tanaman (Sutanto, 2013:56).

Penelitian ini bertujuan untuk mengetahui pengaruh bokashi batang pisang terhadap pertumbuhan dan hasil tanaman bawang daun pada tanah PMK; serta untuk mengetahui dosis bokashi batang pisang yang akan menghasilkan pertumbuhan dan hasil tanaman bawang daun yang tertinggi pada tanah PMK

\section{METODOLOGI PENELITIAN}

\section{Metode Penelitian}

\section{Rancangan Percobaan}

Percobaan ini menggunakan metode Rancangan Acak Kelompok dengan bokashi batang pisang sebagai perlakuan yang terdiri atas 5 perlakuan yaitu $: b_{0}=$ tanpa bokashi batang pisang, $\mathrm{b}_{1}=$ bokashi batang pisang $0,50 \mathrm{~kg}$ per $\mathrm{m}^{2}, \mathrm{~b}_{2}=$ bokashi batang pisang $1,00 \mathrm{~kg}$ per $\mathrm{m}^{2}, \mathrm{~b}_{3}=$ bokashi batang pisang $1,50 \mathrm{~kg}$ per $\mathrm{m}^{2}, \mathrm{~b}_{4}=$ bokashi batang pisang 2,00 $\mathrm{kg}$ per $\mathrm{m}^{2}$

\section{Satuan Percobaan dan Satuan Pengamatan \\ Jumlah tanaman percobaan dalam penelitian ini adalah 12}

tanaman $\times 5$ taraf bokashi batang pisang x 5 ulangan $=375$ tanaman, sedangkan tanaman yang diamati dalam tiap petak percobaan yaitu 2 tanaman, sehingga jumlah tanaman yang diamati adalah 2 tanaman x 5 taraf perlakuan $\times 5$ ulangan $=50$ tanaman

\section{Bahan dan Alat Penelitian}

\section{Bahan}

Bahan yang diperlukan dalam penelitian ini terdiri dari Bibit bawang daun, Air, Furadan 3-G, Prepaton 25 EC dan fungisida Antracol 70 WP, bokashi batang pisang, mulsa plastik.

\section{Alat}

Alat yang digunakan dalam penelitian ini adalah Sabit, Cangkul, Kantong plastik, Gergaji, Triplek, Gunting, Timbangan digital, Ember, Gembor, Mini sprayer, Meteran, Kamera digital, Seperangkat alat tulis

\section{Waktu dan tempat penelitian}

Penelitian ini dilaksanakan mulai dari bulan Januari sampai Maret 2020 Di Desa Jerora I, Kecamatan Sintang, Kabupaten Sintang 
Peranan Bokashi Batang Pisang Dalam Meningkatkan Pertumbuhan Dan Hasil Bawang Daun (Alium fistulosum L.) Pada Tanah PMK

\section{HASIL DAN PEMBAHASAN}

Hasil Penelitian

Hasil Pengamatan dalam

penelitian ini untuk peubah tinggi tanaman, jumlah daun dan berat tanaman disajikan pada Tabel 1

berikut.

Tabel 1. Rerata tiap peubah

\begin{tabular}{cccc}
\hline \multirow{2}{*}{ Perlakuan } & \multicolumn{3}{c}{ Rerata } \\
\cline { 2 - 4 } & Tinggi tanaman & Jumlah daun & Berat tanaman \\
\hline b0 $_{\mathbf{b}}$ & 29.200 & 20.300 & 1.409 \\
$\mathbf{b}_{1}$ & 33.800 & 22.900 & 1.626 \\
$\mathbf{b}_{2}$ & 36.200 & 26.600 & 1.983 \\
$\mathbf{b}_{3}$ & 40.700 & 32.500 & 2.611 \\
$\mathbf{b}_{4}$ & 42.700 & 34.500 & 2.633 \\
\hline Jumlah & $\mathbf{3 6 . 5 2 0}$ & $\mathbf{2 7 . 3 6 0}$ & $\mathbf{2 . 0 5 2}$ \\
\hline
\end{tabular}

Sumber: Data hasil pengamatan

Keteranagn: $b_{0}=$ Tanpa bokashi batang pisang.

$\mathrm{b}_{1}=$ Bokashi batang pisang 5 ton per ha $\left(0,50 \mathrm{~kg}\right.$ per $\left.\mathrm{m}^{2}\right)$.

$\mathrm{b}_{2}=$ Bokashi batang pisang 10 ton per ha $\left(1,00 \mathrm{~kg} \mathrm{per}^{2}\right)$.

$\mathrm{b}_{3}=$ Bokashi batang pisang 15 ton per ha $\left(1,50 \mathrm{~kg} \mathrm{per}^{2}\right)$.

$\mathrm{b}_{4}=$ Bokashi batang pisang 20 ton per ha $\left(2,00 \mathrm{~kg} \mathrm{per}^{2}\right)$.

Rerata hasil pengamatan rata-rata 34,50 daun, sedangkan tinggi tanaman seperti yang terlihat pada Tabel 1 menunjukkan bahwa tanaman tertinggi dihasilkan oleh tanaman yang diberi $2 \mathrm{~kg}$ bokashi batang pisang perlakuan $b_{4}$ dengan tinggi rata-rata $42,70 \mathrm{~cm}$, sedangkan rerata tinggi tanaman terkecil terlihat pada tanaman yang tidak diberi bokashi batang pisang perlakuan $\mathrm{b}_{0}$, yaitu 29,20 $\mathrm{cm}$. Hasil Pengamatan terhadap jumlah daun menunjukkan bahwa tanaman tertinggi dihasilkan oleh tanaman yang diberi $2 \mathrm{~kg}$ bokashi batang pisang dengan tinggi rerata jumlah daun per rumpun terkecil terlihat pada tanaman yang tidak diberi bokashi batang pisang, yaitu 20,30 daun. Hasil pengamatan yang terlihat pada Tabel 1 menunjukkan bahwa tanaman tertinggi dihasilkan oleh tanaman yang diberi $2 \mathrm{~kg}$ bokashi batang pisang dengan berat rata-rata 2,633 $\mathrm{kg}$, sedangkan rerata berat daun per rumpun terkecil terlihat pada tanaman yang tidak diberi bokashi batang pisang, yaitu 1,409 kg. Rerata dari pengamatan tinggi tanaman, 
Peranan Bokashi Batang Pisang Dalam Meningkatkan Pertumbuhan Dan Hasil Bawang Daun (Alium fistulosum L.) Pada Tanah PMK

jumlah daun dan berat tanaman analisis sidik ragam seperti yang kemudian dilanjutkan dengan ditampilkan pada Tabel 2.

Tabel 2. Analisi Ragam Perlakuan Terhadap Tiap Peubah

\begin{tabular}{llllcc}
\hline \multirow{2}{*}{ SK } & \multicolumn{3}{c}{ F hitung } & \multicolumn{2}{c}{ F tabel } \\
\cline { 2 - 5 } & $\begin{array}{l}\text { Tinggi } \\
\text { tanaman }\end{array}$ & $\begin{array}{l}\text { Jumlah } \\
\text { daun }\end{array}$ & Berat segar & $\mathbf{0 , 0 5}$ & $\mathbf{0 , 0 1}$ \\
\hline Kelompok & $1.758^{\text {ns }}$ & $3.226^{*}$ & $3.805^{*}$ & 3.01 & 4.77 \\
Perlakuan & $40.495^{* *}$ & $25.091^{* *}$ & $31.794^{* *}$ & 3.01 & 4.77 \\
\hline
\end{tabular}

Sumber : Hasil analisis data

Keterangan: $\quad n s=$ Tidak berpengaruh pada selang kepercayaan $95 \%$

$* *=$ Berpengaruh pada selang kpercayaan $99 \%$

Hasil analisi sidik ragam pada

Tabel 2 menunjukkan bahwa perlakuan bokashi batang pisang berpengaruh sangat nyata terhadap tinggi tanaman, jumlah daun dan berat segar tanaman bawang daun. dilakukan untuk mengetahui taraf perlakuan pemberian bokashi batang pisang yang terbaik terhadap tinggi tanaman, jumlah daun dan berat segar tanaman daun bawang. Hasil Uji BNJ ditunjukkan pada Tabel 3

\section{Uji Beda Nyata Jujur (BNJ)}

Tabel 3. Uji Beda Nyata Jujur (BNJ) Terhadap Tiap Peubah

\begin{tabular}{|c|c|c|c|}
\hline \multirow{2}{*}{ Perlakuan } & Tinggi Tanaman & Jumlah daun & Berat Segar \\
\hline & \multicolumn{3}{|l|}{ Rerata } \\
\hline bo & $29.200 \mathrm{a}$ & $20.300 \mathrm{a}$ & $1.409 \mathrm{a}$ \\
\hline $\mathbf{b}_{1}$ & $33.800 \mathrm{~b}$ & $22.900 \mathrm{ab}$ & $1.626 \mathrm{ab}$ \\
\hline $\mathbf{b}_{2}$ & $36.200 \mathrm{~b}$ & $26.600 \mathrm{~b}$ & $1.983 \mathrm{~b}$ \\
\hline b3 & $40.700 \mathrm{c}$ & $32.500 \mathrm{c}$ & $2.611 \mathrm{c}$ \\
\hline $\mathbf{b}_{4}$ & $42.700 \mathrm{c}$ & $34.500 \mathrm{c}$ & $2.633 \mathrm{c}$ \\
\hline BNJ 0,05 & 3.676 & 5.253 & 0.429 \\
\hline BNJ 0,01 & 4.661 & 6.660 & 0.544 \\
\hline
\end{tabular}

Sumber : Hasil analisi data

Keterangan : Angka yang diikuti huruf yang sama pada baris atau kolom yang sama menunjukkan berbeda tidak nyata

Hasil Uji BNJ seperti yang terlihat dalam Tabel 3 menunjukkan bahwa pemberian bokashi batang pisang pada dosis $1,50 \mathrm{~kg}$ per $\mathrm{m}^{2}$ $\left(b_{3}\right)$ menghasilkan rerata tinggi tanaman yang tidak berbeda pada selang kepercayaan $95 \%$ dengan dosis $2,00 \mathrm{~kg}$ per $\mathrm{m}^{2}\left(\mathrm{~b}_{4}\right)$, lebih 
Peranan Bokashi Batang Pisang Dalam Meningkatkan Pertumbuhan Dan Hasil Bawang Daun (Alium fistulosum L.) Pada Tanah PMK

tinggi dibanding dosis $1,00 \mathrm{~kg}$ per $\mathrm{m}^{2}$ $\left(b_{2}\right), \quad 0,50 \mathrm{~kg}$ per $\mathrm{m}^{2}\left(\mathrm{~b}_{1}\right)$, dan tanpa pemberian bokashi batang pisang $\left(b_{o}\right)$. Berdasarkan hasil uji BNJ tersebut dinyatakan bahwa perlakuan yang memberikan rerata tinggi tanaman tertinggi adalah perlakuan $\mathrm{b}_{3}$. Pada perlakuan tersebut menghasilkan rerata tinggi tanaman 40,700 cm. Untuk peubah jumlah daun menunjukkan bahwa pemberian bokashi batang pisang pada dosis $1,50 \mathrm{~kg}$ per $\mathrm{m}^{2} \quad\left(\mathrm{~b}_{3}\right)$ menghasilkan rerata jumlah daun per rumpun yang tidak berbeda pada selang kepercayaan $95 \%$ dengan dosis 2,00 $\mathrm{kg}$ per $\mathrm{m}^{2}\left(\mathrm{~b}_{4}\right)$, lebih banyak dibanding dosis $1,00 \mathrm{~kg}$ per $\mathrm{m}^{2}\left(\mathrm{~b}_{2}\right)$, $0,50 \mathrm{~kg}$ per $\mathrm{m}^{2}\left(\mathrm{~b}_{1}\right)$, dan tanpa pemberian bokashi batang pisang $\left(b_{o}\right)$. Berdasarkan hasil uji BNJ tersebut dinyatakan bahwa perlakuan yang memberikan rerata jumlah daun per rumpun terbanyak adalah perlakuan $b_{3}$. Pada perlakuan tersebut menghasilkan rerata jumlah daun per rumpun 32,500 buah. Hasil Uji BNJ untuk peubah berat tanaman menunjukkan bahwa bahwa pemberian bokashi batang pisang pada dosis $1,50 \mathrm{~kg}$ per $\mathrm{m}^{2} \quad\left(\mathrm{~b}_{3}\right)$ menghasilkan rerata berat tanaman per rumpun yang tidak berbeda pada selang kepercayaan $95 \%$ dengan dosis $2,00 \mathrm{~kg}$ per $\mathrm{m}^{2}\left(\mathrm{~b}_{4}\right)$, lebih berat dibanding dosis $1,00 \mathrm{~kg}$ per $\mathrm{m}^{2}\left(\mathrm{~b}_{2}\right)$, $0,50 \mathrm{~kg}$ per $\mathrm{m}^{2}\left(\mathrm{~b}_{1}\right)$, dan tanpa pemberian bokashi batang pisang $\left(b_{o}\right)$. Berdasarkan hasil uji BNJ tersebut dinyatakan bahwa perlakuan yang memberikan rerata berat tanaan per rumpun terberat adalah perlakuan $b_{3}$. Pada perlakuan tersebut menghasilkan rerata berat tanaman per rumpun $0,261 \mathrm{~kg}$.

\section{Pembahasan}

Hasil penelitian menunjukkan bahwa bokashi batang pisang berpengaruh terhadap tinggi tanaman, jumlah daun, dan berat tnaman. Hasil penelitian ini menunjukkan bahwa bokashi batang pisang dapat meningkatkan pertumbuhan dan hasil bawang daun. Peningkatan pertumbuhan dan hasil akibat pemberian bokashi batang pisang ini diduga tanah lingkungan tumbuh tanaman menjadi lebih gembur, karena bokashi batang pisang merupakan pupuk organik.

$$
\text { Yuwono }
$$

menjelaskan bahwa bokashi batang pisang di dalam tanah akan 
Peranan Bokashi Batang Pisang Dalam Meningkatkan Pertumbuhan Dan Hasil Bawang Daun (Alium fistulosum L.) Pada Tanah PMK

menyumbang bahan organik ke dalam tanah. Sutanto (2013:47) menjelaskan bahwa peran utama dari bagan organik adalah menyumbang bahan organik ke dalam tanah.

Hakim, dkk. (1996:137-138) menjelaskan bahwa peran bahan organik di dalam tanah adalah meningkatkan kemampuan tanah untuk menahan air, merangsang grnulasi tanah, menurunkan plastisitas tanah, meningkatkan daya jerap dan KTK tanah, meningkatkan jumlah kation yang dapat dipertukrkan, mengurangi kehilangan unsur N, P, dan S akibat pencucian, karena unsur trsebut terikat dalam bentuk organik, melepaskan hara yang terikat oleh partikel tanah menjadi tersedia bagi tanaman, dan meningkatkan jumlah serta aktivitas mikro-organisme tanah. Berdasarkan pnjelasan Hakim, dkk. (1996:137138) tersebut lingkungan tumbuh bagi tanaman menjadi lebih baik dan penyerapan hara meningkat.

Selain dapat menyumbang bahan organik ke dalam tanah, bokashi batang pisang juga dapat menyumbang unsur hara ke dalam tanah terutama $\mathrm{N}$ dan $\mathrm{P}$, karena bokashi batang pisang mempunyai kandungan $\mathrm{K}(7,5 \%)$ dari bahan kering dan $\mathrm{P}(6,0 \%)$ dari bahan kering (Anonim, 2018:1). Gardner, Perace, dan Mitchell, 2001:137-139) menjelaskan bahwa unsur $\mathrm{N}$ dan $\mathrm{P}$ amat penting pranannya bagi pertumbuhan dan hasil tanaman. Unsur $\mathrm{N}$ dan $\mathrm{P}$ setelah diserap oleh tanaman akan mempunyai peran fisiologis bagi tanaman.

Peran fisiologis $\mathrm{N}$ adalah sebagai bahan penyusun asam amino, amida, nuklotida, dan nukleoprotein, serta esensial untuk pembelahan sel, perkembangan sel, oleh karenanya $\mathrm{N}$ penting untuk pertumbuhan tanaman (Gardner, Pearce, dan Mitchell, 2001:146-150). Peran fisiologis $\mathrm{P}$ adalah merupakan bagian yang esensial dari berbagai gula pospat yang amat berperan dalam reaksi metabolisme tumbuhan (Lakitan, 2001:67). Dwijoseputro (1999:29) menjelaskan bahwa $P$ juga merupakan bahan penyusun fosfolipid, senyawa ini memegang peranan penting dalam integritas membran sel. Sutejo (2014:26) menjelaskan bahwa $\mathrm{P}$ sangat diperlukan dalam pertumbuhan akar tanaman 
KESIMPULAN DAN SARAN

\section{Kesimpulan}

Hasil analisis data dalam penelitian ini disimpulkan sebagai berikut:

1. Bokashi batang pisang berpengaruh terhadap pertumbuhan dan hasil bawang daun, yang ditunjukkan oleh peubah tinggi tanaman, jumlah daun, dan berat tanaman.

2. Pertumbuhan dan hasil tertingi akibat pemberian bokashi batang pisang dicapai pada dosis $1,50 \mathrm{~kg}$ per $\mathrm{m}^{2}$, pada dosis tersebut menghasilkan rerata tinggi tanaman $40,700 \mathrm{~cm}$, rerata jumlah daun per rumpun 32,500 buah, dan rerata berat tanaman per rumpun $0,261 \mathrm{~kg}$.

\section{Saran}

Berdasarkan hasil penelitian ini disarankan untuk:

1. Pemberian bokashi batang pisang dapat diterapkan untuk meningkatkan pertumbuhan dan hasil bawang daun.

2. Pemberian bokashi batang pisang $1,50 \mathrm{~kg}$ pert $\mathrm{m}^{2}$ dapat diterapkan untuk sekala petani dalam memaksimalkan pertumbuhan dan hasil bawang daun.
DAFTAR PUSTAKA

AAK. 2014. Petunjuk Praktis Bertanam Sayuran. Jakarta:Puspaswara.

Badan Pusat Statistik Kabupaten Sintang 2018. Sintang Dalam Angka. Sintang: Badan Pusat Statistik Kabupaten Sintang.

Badan Pusat Statistik Kalimantan Barat. 2018. Kalimantan Barat Dalam Angka. Pontianak: BPS Kalimantan Barat.

Balai Rehabilitasi Lahan dan Konservasi Tanah Solo. 2013. Petunjuk Tentang Efektivitas Mikro-organisme EM4. Solo: Balai Rehabilitasi Lahan dan Konservasi Tanah Solo.

Darmawijaya, M. 1992. Klasifikasi Tanah, Yogyakarta: Gajah Mada University Press.

Dwidjoseputro, D. 1999. Pengantar Fisiologi Tumbuhan. Jakarta: Gramedia.

Gardner, F.P., Pearce, R.B., dan Mitchell, R.L. 2001. Diterjemahkan oleh Herawati, S. Fisiologi Tumbuhan Budidaya. Jakarta: Universitas Indonesia.

Gaspersz, V. 1994. Metode Rancangan Percobaan. Bandung: Armico.

Hakim, N., Nyakpa, M.Y., Lubis, A.M., Sutopo, G.N., Saul, M.R., Diha, M.A., Go Ban 
Peranan Bokashi Batang Pisang Dalam Meningkatkan Pertumbuhan Dan Hasil Bawang Daun (Alium fistulosum L.) Pada Tanah PMK

Hong, dan Bailey, H.H. 1996. Dasar Dasar Ilmu

Tanah. Bandar Lampung: Universitas Lampung.

Hanafiah, K.A. 2012. Perancangan Percobaan: Teori dan Aplikasi. Palembang: Universitas Sriwijaya.

Hardjowigeno, H. 2010. Ilmu Tanah. Jakarta: Akademik Presindo.

Lakitan, B. 2015. Dasar Dasar Fisiologi Tumbuhan. Jakarta: Raja Grafindi Perkasa.

Lingga, P dan Marsomo. 2012. Pupuk dan Petunjuk Penggunaan Pupuk. Jakarta: Penebarswadaya.

LPTP Pontianak. 2001. Rekomendasi Pertanian Di Kalimantan Barat. Pontianak: LPTP Pontianak.

Nazaruddin. 2013. Budidaya Sayuran Dataran Rendah. Jakarta: Penebar Swadaya.

Nykpa, M.Y., Lubis, A.M., Pulung, M.A., Amrah, A.G., Munawar, A., Go Ban Hong, dan Hakim, N. 1998. Kesuburan Tanah, Lampung:Universitas Lampung.
Sastrosupardi, A. 1999. Perancangan Percobaan Bidang Pertanian. Yogyakarta: Kanisius.

Soegiman. 1982. Ilmu Tanah. Terjemahan Dari Buckman, H.O. and Brady, N.C. Jakarta: Bharata Karya Aksara.

Sugeng, H.R. 2013. Bercocok Tanam Sayuran. Semarang: Aneka Ilmu.

Sunaryono, H. 2012. Bercocok Tanam Bawang Daun. Jakarta: Penebar Swadaya.

Sutanto.R. 2013. Pertanian Organik. Yogyakarta: Kanisius.

Sutejo, M.M. 2014. Pupuk dan Cara Pemupukan. Jakarta: Rineka Cipta.

Wibowo,S. 2014. Budidaya Bawang. Jakarta: Penebar Swadaya

Yitnosumarto, S. 1999. Perancangan Percobaan dan Interpretasinya. Jakarta: Gramedia,

Yuwopno, D. 2015. Kompos Dengan Aerob Maupun Anaerob. Jakarta: Penebar Swadaya 